Annals of Warsaw University of Life Sciences - SGGW

Land Reclamation No 42 (2), 2010: 229-240

(Ann. Warsaw Univ. of Life Sci. - SGGW, Land Reclam. 42 (2), 2010)

\title{
Modelling of the effects of land use changes on flood hydrograph in a small catchment of the Plaskowicka, southern part of Warsaw, Poland
}

\author{
KAZIMIERZ BANASIK ${ }^{1}$, NGOC PHAM ${ }^{2}$
}

${ }^{1}$ Department of Water Engineering, Warsaw University of Life Sciences - SGGW

${ }^{2}$ Interfaculty Study of Environmental Protection, Warsaw University of Life Sciences - SGGW

\begin{abstract}
Modelling of the effects of land use changes on flood hydrograph in a small catchment of the Ptaskowicka, southern part of Warsaw, Poland. This study concerns the influence of urbanized trend affected on the flood hydrograph in a small catchment in Warsaw. Based on recorded events a selected procedure for simulation rainfall-runoff process has been accepted for flood estimation. The Soil Conservation Services Curve Number method (SCS-CN) and empirical formulae for Nash model parameters, developed by Rao at al. were used to analyze the nine selected events from 2007 to 2009 . The analysis confirmed usefulness of the selected procedure, implicated in a home developed computer program, for estimating flood hydrographs as responses of the small urban catchment to heavy rainfall events. Flood hydrographs were estimated for three various stages of land use. The results demonstrate that the peak flood flow would increase over eight times due to urbanisation of the catchment.
\end{abstract}

Key words: Land use changes, flood hydrograph, SCS-CN method, urban flood, Rao formulae, rainfall-runoff process.

\section{INTRODUCTION}

More and more human's activities explore the nature to urbanize, industrialize, construct roads, airports, etc. The general effect of urbanisation on hydrological characteristics of a chatchment is to reduce the amount of infiltration into the ground and to increase the speed of runoff. The effect of urbanization on surface water quality and quantity is recently quite often investigated (Banasik at al. 2008; Crooks, Davies 2001). The aim of this study has been to assess the influence of urbanisation on flood hydrograph of a small catchment located in the south of Warsaw. Based on recorded events, a selected procedure for simulation rainfall-runoff process has been accepted for flood estimation. The Soil Conservation Services Curve Number method - SCS-CN (SCS 1972, 1986) and empirical formulae for Nash model parameters, developed by Rao at al. (1972) were used to analyze the nine selected events from 2007 to 2009. The catchment, which urbanisation started in the late 70-ties of the previous centry, is nearly totally urbanized now. The flood hydrographs, as responses of the catchement to rainfall events of return period of 10-years and various duration, were estimated for three different stages of urbanisation i.e. initial land use (no urbanisation), intermediate one (ca 1985) and the current one. The procedure, which is described later, is the same as applied earlier to near located stream (Banasik at al. 2008). 


\section{STUDY AREA DESCRIPTION}

The Płaskowicka catchment, nearly totally urbanized for the last few years, is located in the south of Warsaw, within the Ursynow district (Fig. 1). Its area is $5.0 \mathrm{~km}^{2}$ and the impervious fraction is about $65 \%$. Very rapid urbanization started in the late 70-ties, reaching in the middle of 80 -ties ca $40 \%$ of the catchment area, with catchment's impervious fraction ca. $20 \%$. Sandy soils occupy ca $8 \%$ of the catchment area and the sand with clay or silt occupies the remaining part (Pham 2010). Average annual temperature is $7.6^{\circ} \mathrm{C}$ (mean temperature in July $18.5^{\circ} \mathrm{C}$ ), and average annual precipitation is $542 \mathrm{~mm}$ (Majewski et al. 2010). The storm water is collected by pipes and main collector, which outlet is connected to Wolica Ditch, being right tributary of Służew Creek. The Służew Creek has its outlet to Wilanów Lake, which is connected via Wilanówka River with the Vistula River.

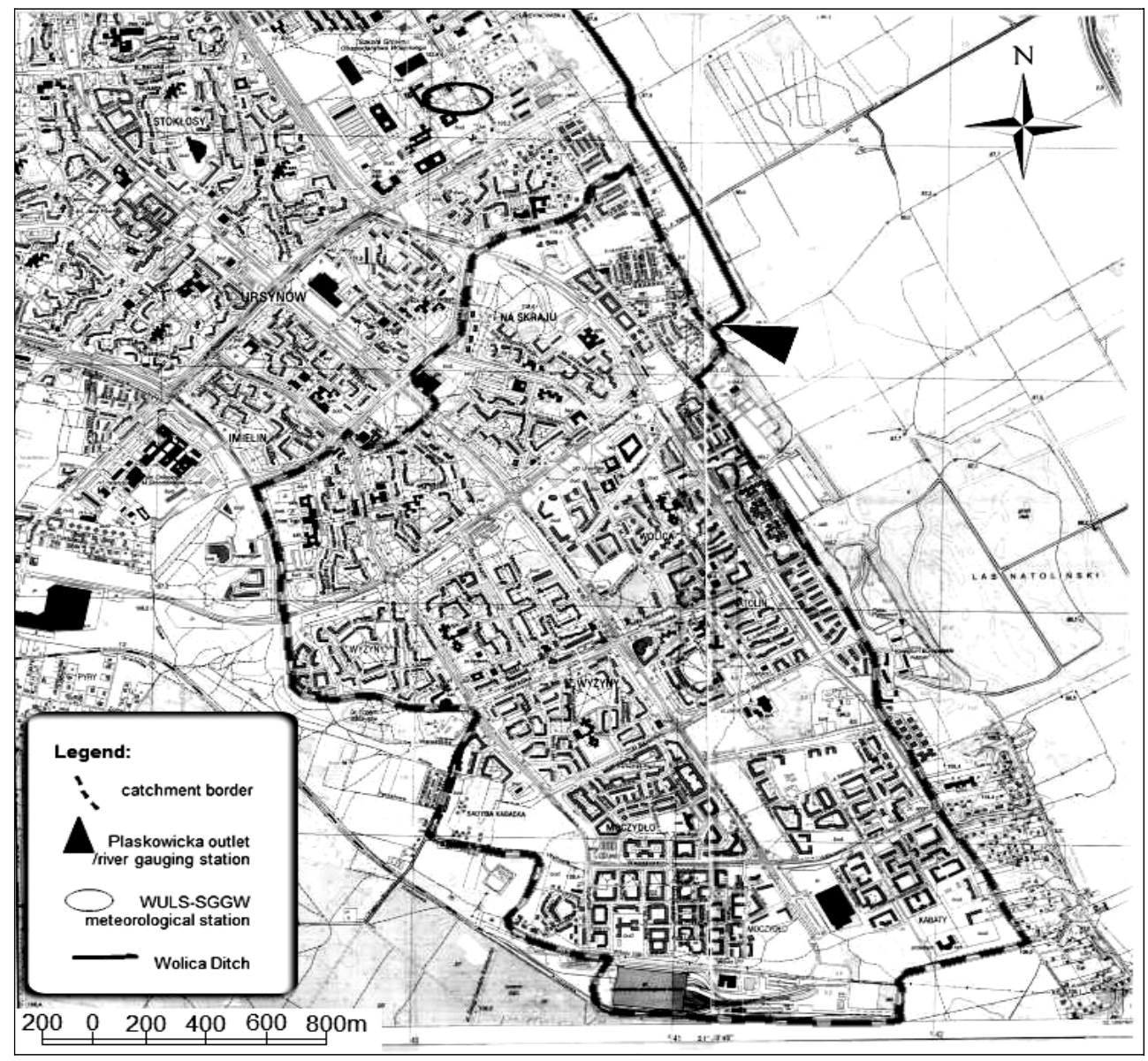

FIGURE 1. Płaskowicka catchment 


\section{DATA USED AND METHODS}

\section{Rainfall - Runoff data collection}

Rainfall data were collected at meteorological station of Warsaw University of Life Sciences - SGGW, which is located just at the northern border of the Plaskowicka catchment (Fig. 1). A tipping bucket rain gauge is one of the typical meteorological devices applied to measure the amount of precipitation.

Water level recorder with pressure sensor allowed registering the water stages at the outlet of the catchment, with the time step of 10 minutes. This data with rating curve, estimated on the base of channel cross-section area and Manning's formula for mean velocity (Ankiewicz 2003), allowed to estimate the discharge at the catchment's outlet.

\section{Data analysis}

Rainfall-runoff data were analyzed to estimate Curve Number as parameter of effective rainfall computation, and to assess a function for transformation of the effective rainfall into direct runoff hydrograph.

Using measured rainfall - runoff data, the empirical $\mathrm{CN}$ - value is estimated by the use of the relationship (Hawkins 1985; Banasik and Woodward 2010):

$C N=\frac{25400}{S+254}$

where $\mathrm{S}$ is the catchment storage parameter $(\mathrm{mm})$ computed from the formula:

$$
S=5\left(P+2 H-\left(4 H^{2}+5 P H\right)^{0.5}\right)
$$

where $\mathrm{P}$ is rainfall depth $(\mathrm{mm})$ and $\mathrm{H}$ is effective rainfall depth $(\mathrm{mm})$, assumed as equal to direct runoff, estimated from runoff hydrograph volume after subtracting base flow volume. Having the $\mathrm{CN}$ value, the effective rainfall is computed from the total rainfall by the use of the formula:

$$
\begin{gathered}
H_{j}=\sum_{l}^{j} \Delta H_{l}=\left\{\begin{array}{l}
0 \\
\frac{\left(P_{j}-0.2 S\right)^{2}}{P_{j}+0.8 S}
\end{array}\right. \\
P_{j}-0.2 S \leq 0
\end{gathered}
$$

with

$$
P_{j}-0.2 S>0
$$

A conceptual model as proposed by Nash (1957), i.e. a cascade of N-linear reservoirs, of equal storage coefficient, has been used to transform the effective rainfall into direct runoff hydrograph. The outflow from the first reservoir is considered as inflow into the second reservoir, and so on. The outflow from the Nth reservoir, i.e. the instantaneous unit hydrograph (IUH), is considered as catchment response to unit effective rainfall. The IUH has a form of gamma probability density function given by:

$u(t)=\frac{1}{k \Gamma(N)} \cdot(t / k)^{N-1} \exp (-t / k)$

where:

$\mathrm{u}(\mathrm{t})$ are the ordinates of IUH $(1 / \mathrm{h})$;

$\mathrm{t}-$ is time from beginning of the event (h);

$\mathrm{k}$ - is the storage coefficient (h);

$\mathrm{N}-$ is the number of linear reservoirs $(-)$.

Methods of moments were used to estimate the model parameters ( $\mathrm{N}$ and k) for each event, based on the effective 
rainfall and direct runoff hydrograph. The parameters were estimated to compare them with an empirical formula of Rao et al. (1972).

One of the characteristic values in rainfall-runoff modelling is the retention of the system or lag time, which is defined as the time elapsed between the centroids of effective rainfall and the direct runoff hydrograph. According to Rao et al. (1972) the lag time and the model parameter $\mathrm{k}$ depend on the size of catchment, duration of rainfall event, fraction of impervious area in the catchment, and the runoff (i.e. effective rainfall) depth. They can be estimated by computing the Lag time from the formulae:

$L A G=1.28 \cdot A^{0.46} \cdot(1+U)^{-1.66} \cdot H^{-0.27} \cdot D^{0.37}$

and the retention parameter:

$k=0.56 \cdot A^{0.39} \cdot(1+U)^{-0.62} \cdot H^{-0.11} \cdot D^{0.22}(6)$

where:

$\mathrm{U}-$ is fraction of impervious area (-)

$\mathrm{D}$ - is duration of effective rainfall (mm),

A - is total area of the catchment $\left(\mathrm{km}^{2}\right)$. The number of reservoirs is computed from the formula:

$$
N=\frac{L A G}{k}
$$

\section{RESULTS AND DISCUSSION}

The main parameters of the nine recorded rainfall-runoff events, according to descending rainfall depth, of the period from 2007 to 2009 are displayed in Table 1 . They clearly present the range of rainfall depth, i.e. from $3.4 \mathrm{~mm}$ to $52.8 \mathrm{~mm}$, as well as runoff depth from $2.57 \mathrm{~mm}$ to
$8.64 \mathrm{~mm}$. The $\mathrm{CN}$-values estimated according to the formula 1 and 2 from the data $\mathrm{P}$ and $\mathrm{H}$ given in table 1; vary from 72.5 to 99.7 with the mean of 91.2 .

The value of theoretical $\mathrm{CN}$, estimated on the base of land use and soil types, is 84.4 (Pham 2010). These results confirm earlier findings (Hawkins et al. 1993; Banasik, Woodward 2010) that small events overestimate the representative $\mathrm{CN}$ for the catchment. So only larger events are considered for finding the representative $\mathrm{CN}$, based on mean retention parameter $S_{m}$ (Tab. 1, column 7), which is computed from the formula:

$S_{m}=\sum_{j=1}^{i} S_{j} / i$

where $S_{m}$ is the mean value for $S$ for storm (i) and all larger events i.e. when storms have been placed in order from the largest to the smallest rainfall depth. The valuse $\mathrm{S}_{\mathrm{m}}$ is increasing from 72.5 to 91.2 (Tab. 1, column 9 and Fig. 2) with the rainfall depth decreasing from the largest one to the lowest one. The $\mathrm{CN}$-value for the four largest events, according to rainfall depth, i.e. for $\mathrm{P}>10 \mathrm{~mm}$ is 84.4 and for the five largest events, i.e. for $\mathrm{P} \geq 9.7 \mathrm{~mm}$, is 85.9 , so it is very close to the theoretical one. As indicated by Banasik and Woodward (2010), the threshold - for taking into consideration the largest recorded rainfall-runoff events to estimate representative $\mathrm{CN}$ of the catchment - is the value of rainfall depth equal to initial abstraction coresponding to the theoretical $\mathrm{CN}$. For the theoretical $\mathrm{CN}=$ $=84.6$, the initial abstraction, computed as $0.2 \mathrm{~S}$ i.e. $20 \%$ of maximum catchment retention, is $9.4 \mathrm{~mm}$. 
TABLE 1. Characteristics of nine largest selected rainfall runoff events

\begin{tabular}{|c|c|c|c|c|c|c|c|c|}
\hline No & Date & $\begin{array}{l}\text { Rainfall } \\
\text { Pi (mm) }\end{array}$ & $\begin{array}{l}\text { Runoff } \\
\mathrm{Hi}(\mathrm{mm})\end{array}$ & $\begin{array}{c}\text { Curve } \\
\text { Number } \\
\text { CNi }\end{array}$ & $\begin{array}{c}\text { Max } \\
\text { retention } \\
\mathrm{Si}(\mathrm{mm})\end{array}$ & $\begin{array}{c}\text { Mean } \\
\text { retention } \\
\mathrm{Sm}(\mathrm{mm})\end{array}$ & $\mathrm{Pi} / \mathrm{Sm}$ & $\mathrm{CNm}$ \\
\hline 1 & 2 & 3 & 4 & 5 & 6 & 7 & 8 & 9 \\
\hline 1 & 25.06.2009 & 52.8 & 8.64 & 72.48 & 96.45 & 96.45 & 0.55 & 72.48 \\
\hline 2 & 09.06 .2009 & 43.3 & 5.78 & 74.22 & 88.22 & 92.34 & 0.47 & 73.35 \\
\hline 3 & 30.05 .2009 & 13.5 & 4.98 & 95.14 & 12.97 & 65.88 & 0.20 & 80.61 \\
\hline 4 & 02.07 .2007 & 10.6 & 3.45 & 95.63 & 11.60 & 52.31 & 0.20 & 84.37 \\
\hline 5 & 16.07.2009 & 9.7 & 0.97 & 91.84 & 22.56 & 46.36 & 0.21 & 85.86 \\
\hline 6 & 12.08 .2007 & 5.1 & 1.85 & 98.07 & 4.99 & 39.47 & 0.13 & 87.90 \\
\hline 7 & 28.05.2009 & 4.2 & 0.65 & 96.98 & 7.92 & 34.96 & 0.12 & 89.20 \\
\hline 8 & 22.05.2009 & 4.1 & 0.62 & 97.01 & 7.83 & 31.57 & 0.13 & 90.17 \\
\hline 9 & 19.06 .2007 & 3.4 & 2.57 & 99.67 & 0.83 & 28.15 & 0.12 & 91.23 \\
\hline & Mean values & 16.3 & 3.28 & 91.23 & 28.15 & & & \\
\hline
\end{tabular}

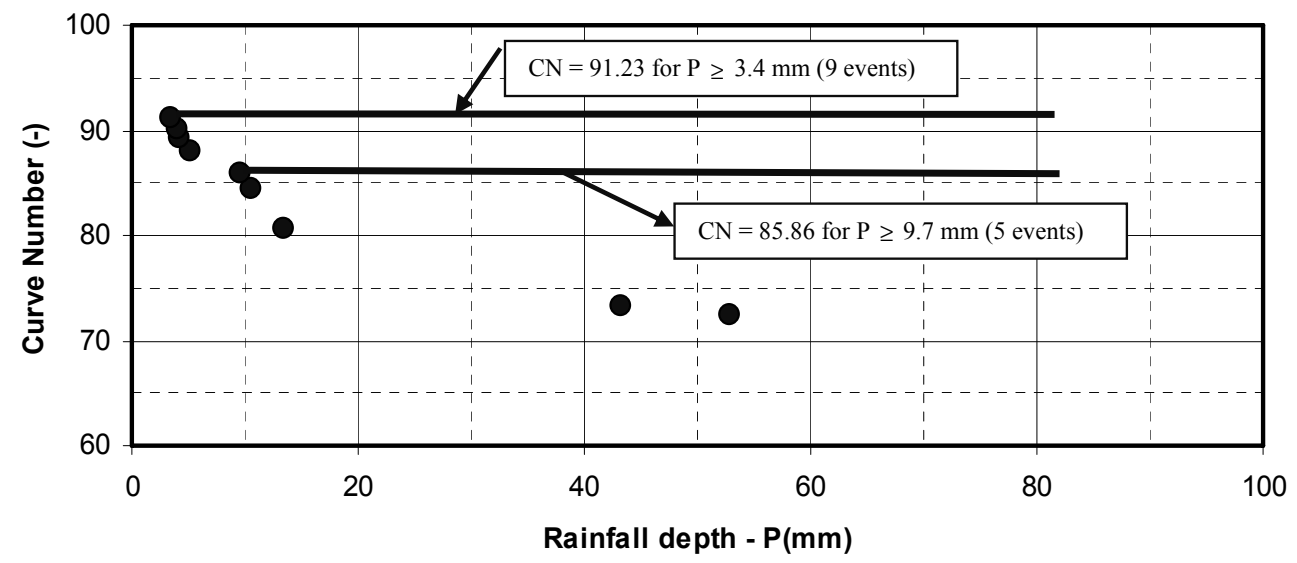

- Events from 2007-2009

FIGURE 2. Curve Number versus rainfall depth

The catchment lag times estimated from the recorded rainfall-runoff events and according to Rao formula (equation 5) with relation to effective rainfall are presented on the Figure 3. One can find that for larger events i.e. $\mathrm{H}>2.5 \mathrm{~mm}$, the difference between the lag times estimated with the two methods are smaller (ex- cept one event), than for smaller events i.e. with $\mathrm{H}<2.5 \mathrm{~mm}$. The differences in lag times for smaller events and one of the larger could be caused by various reasons, from which direction of cloud movement (according to flow direction or in opposite direction) may be the major reason. Detailed model parameters 


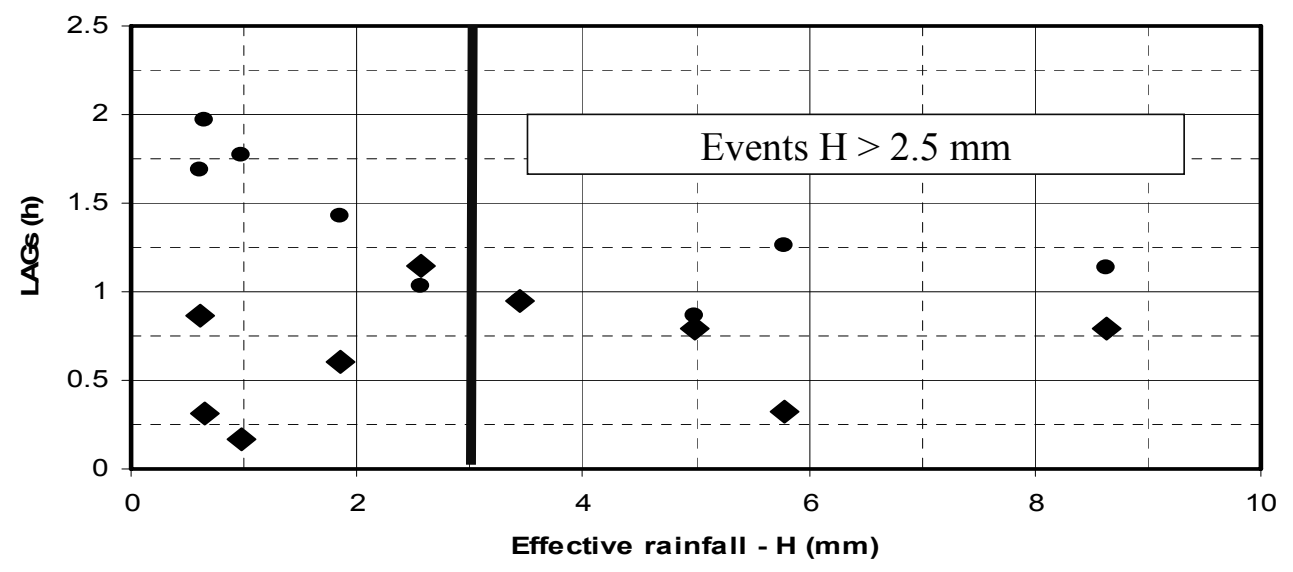

Rao formula - Method of moments

FIGURE 3. Comparison of LAGs of recorded events estimated according to methods of moments and Rao formula

( $\mathrm{N}$ and $\mathrm{k}$ ) estimated from the four events of $\mathrm{H}>2.5 \mathrm{~mm}$ with close lag times of two methods of estimation are presented in the Table 2.

For computation of the parameters the SNE computer program, developed in the Department of Water Engineering of WULS - SGGW, was used. For extraction of the effective rainfall distribution from total rainfall and estimation of the parameters $\mathrm{N}$ and $\mathrm{k}$ the $\mathrm{CN}-\mathrm{SCS}$ method was applied. The comparison of lag time and model parameters, estimated from the recorded events and Rao formula, demonstrates good agreement of the results in Table 2.

This is why the Rao formula has been accepted for further analysis for this catchment.

TABLE 2. Characteristics and parameters of the four recorded rainfall-runoff events

\begin{tabular}{|c|c|c|c|c|c|c|c|c|c|c|c|}
\hline \multicolumn{3}{|c|}{ Rainfall characteristics } & \multicolumn{8}{|c|}{ Nash model parameters and IUH characteristics } & \multirow{3}{*}{$\begin{array}{c}\text { Max runo- } \\
\text { ff dischar- } \\
\text { ge }-\mathrm{Q}_{\max } \\
\left(\mathrm{m}^{3} / \mathrm{s}\right)\end{array}$} \\
\hline \multirow[b]{2}{*}{ Date } & \multirow{2}{*}{$\begin{array}{l}\text { Dura- } \\
\text { tionD } \\
\text { (h) }\end{array}$} & \multirow{2}{*}{$\begin{array}{l}\text { Effec- } \\
\text { tive } \\
\text { rainfall } \\
\text { depthH } \\
(\mathrm{mm})\end{array}$} & \multicolumn{4}{|c|}{$\begin{array}{l}\text { according to methods } \\
\text { of moments }\end{array}$} & \multicolumn{4}{|c|}{ according to Rao formula } & \\
\hline & & & $\begin{array}{l}\text { LAG } \\
\text { (h) }\end{array}$ & $\begin{array}{l}\mathrm{N} \\
(-)\end{array}$ & $\begin{array}{l}\mathrm{k} \\
(\mathrm{h})\end{array}$ & $\begin{array}{l}\mathrm{u}(\mathrm{t}) \\
(1 / \mathrm{h})\end{array}$ & $\begin{array}{l}\text { LAG } \\
\text { (h) }\end{array}$ & $\begin{array}{l}\mathrm{N} \\
(-)\end{array}$ & $\begin{array}{l}\mathrm{k} \\
(\mathrm{h})\end{array}$ & $\begin{array}{l}\mathrm{u}(\mathrm{t}) \\
(1 / \mathrm{h})\end{array}$ & \\
\hline 1 & 2 & 3 & 4 & 5 & 6 & 7 & 8 & 9 & 10 & 11 & 12 \\
\hline 02/07/07 & 1.50 & 3.45 & 0.95 & 1.00 & 0.95 & 0.13 & 0.95 & 1.31 & 0.73 & 0.28 & 3.97 \\
\hline $19 / 06 / 07$ & 1.50 & 2.57 & 1.15 & 1.49 & 0.77 & 0.32 & 1.03 & 1.37 & 0.75 & 0.29 & 3.45 \\
\hline $30 / 05 / 09$ & 1.50 & 4.98 & 0.79 & 1.00 & 0.79 & 0.17 & 0.86 & 1.23 & 0.70 & 0.26 & 3.85 \\
\hline 25/06/09 & 4.67 & 8.64 & 0.79 & 1.00 & 0.79 & 0.02 & 1.13 & 1.34 & 0.85 & 0.04 & 4.83 \\
\hline \multicolumn{3}{|c|}{ Average value } & 0.92 & 1.12 & 0.83 & 0.16 & 0.99 & 1.31 & 0.76 & 0.22 & 4.03 \\
\hline
\end{tabular}


Prediction of catchment response to designed rainfall events with $p=10 \%$ and different durations, at various stages of land use

In order to compare the differences in responses of the catchment to rain events at various stages of land use, the rain events of probability $\mathrm{p}=10 \%$ and various duration $(\mathrm{D}=0.5 ; 1 ; 2 ; 4 ; 6 ; 8 ; 10$ hours) have been assumed in the investigation. Basing on the relationship of intensity-duration-return period, which is applicable for center of Poland (Bogdanowicz, Stachy, 1998) the rainfall depths were found. The prediction has been carried out for the current land use (2006-2009), earlier one i.e 1985 and initial one i.e before urbanization started, applying procedure described by Banasik (2009) and Banasik at al. (2000). For all land use stages the effective rainfall was computed on the base of theoretical CN and model parameters were estimated according to Rao formulae.

The computed intensity $-\mathrm{I}_{\mathrm{p}}=10 \%$ versus rain duration $-\mathrm{D}$, as well as the effective rainfall fo $\mathrm{CN}=84.4$ i.e for cur- rent land use, was shown in the Figure 4. The computed direct runoff hydrograph are shown on the Figure 5.

One can notice from Figure 5 that at the beginning $(\mathrm{D}=0.5-2 \mathrm{~h})$ the peak discharges increased with rain duration, reaching the value of $8.9 \mathrm{~m}^{3} / \mathrm{s}$ for $\mathrm{D}=$ $2 \mathrm{~h}$. It is worth to notice that the predicted peak discharge is higher than the capacity of out flow pipe (collector), which is $6 \mathrm{~m}^{3} / \mathrm{s}$. The direct runoff hydrographs computed as catchment responses to the same rainfall events, but at earlier land use in the catchment $(\mathrm{CN}=78.74)$ and the initial one $(\mathrm{CN}=69)$ are presented in the Figures 6 and 7.

Direct runoff hydrographs presented on Figures 6 and 7 demonstrate that the highest peak discharge would be caused by rain of $\mathrm{D}=2 \mathrm{~h}\left(\mathrm{Q}_{\max }=4.2 \mathrm{~m}^{3} / \mathrm{s}\right)$ for earlier land use (as in 1985), and of $\mathrm{D}=6 ; 8 ; 10 \mathrm{~h}\left(\mathrm{Q}_{\max }=1.1 \mathrm{~m}^{3} / \mathrm{s}\right)$ for agricultural land use (as in 1978) in the catchment. The results of the analysis in a condense form are presented in the Figure 8 and in the Table 3 which showed that there is a significant increase of

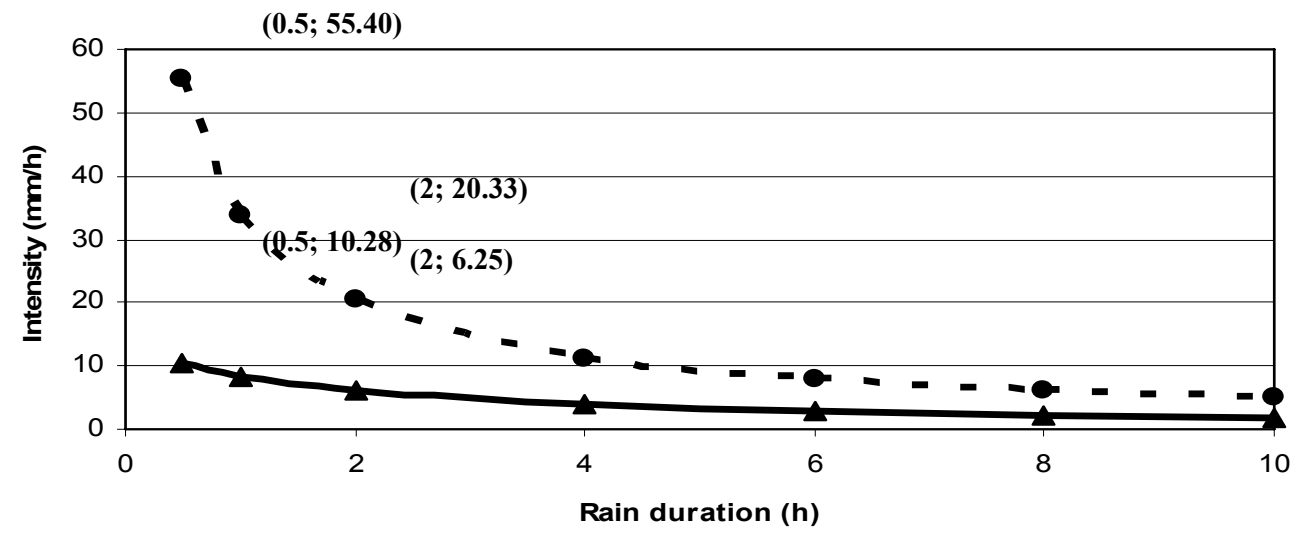

FIGURE 4. Average intensity and intensity of effective rainfall versus rain duration with 10 -year period, for current land use 2006 (values in parenthesis are rain duration and mean rain intensity) 


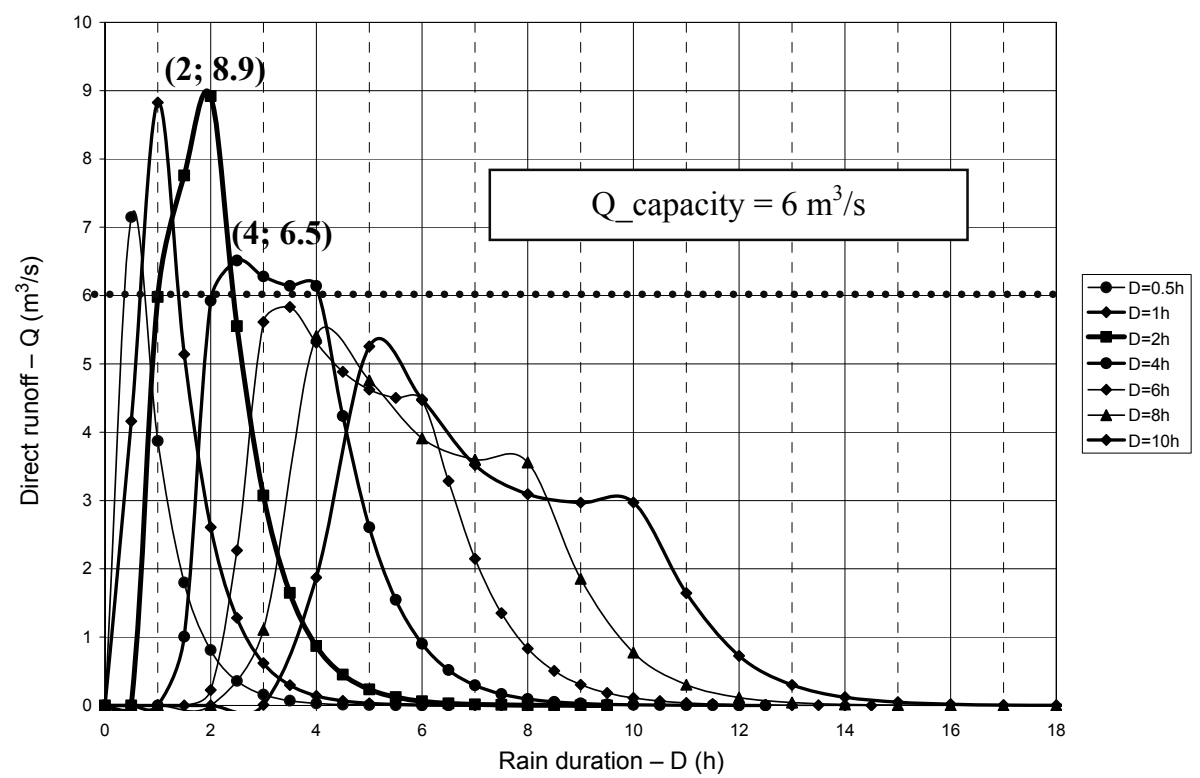

FIGURE 5. Runoff hydrographs caused by rainfall events of return period of 10 years and various duration, at current land use in the catchment (2006-2009)

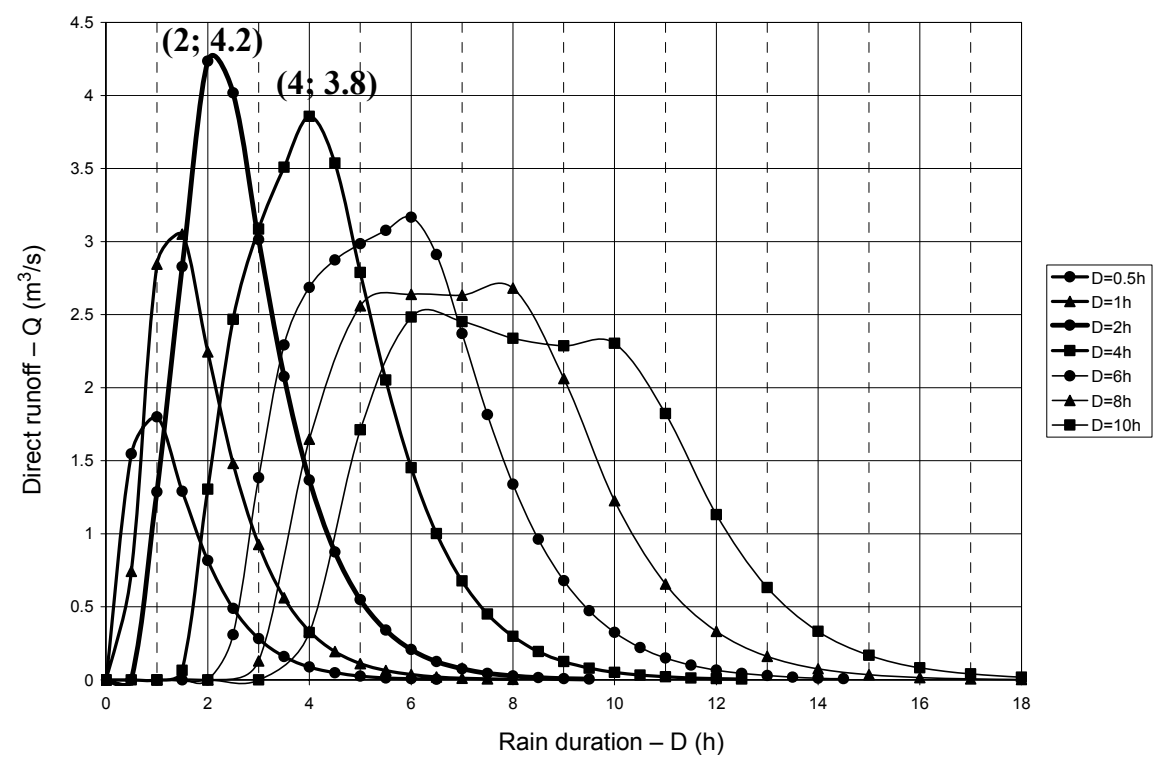

FIGURE 6. Runoff hydrographs caused by rainfall events of return period of 10 years and various duration, at earlier land use in the catchment (1985) 


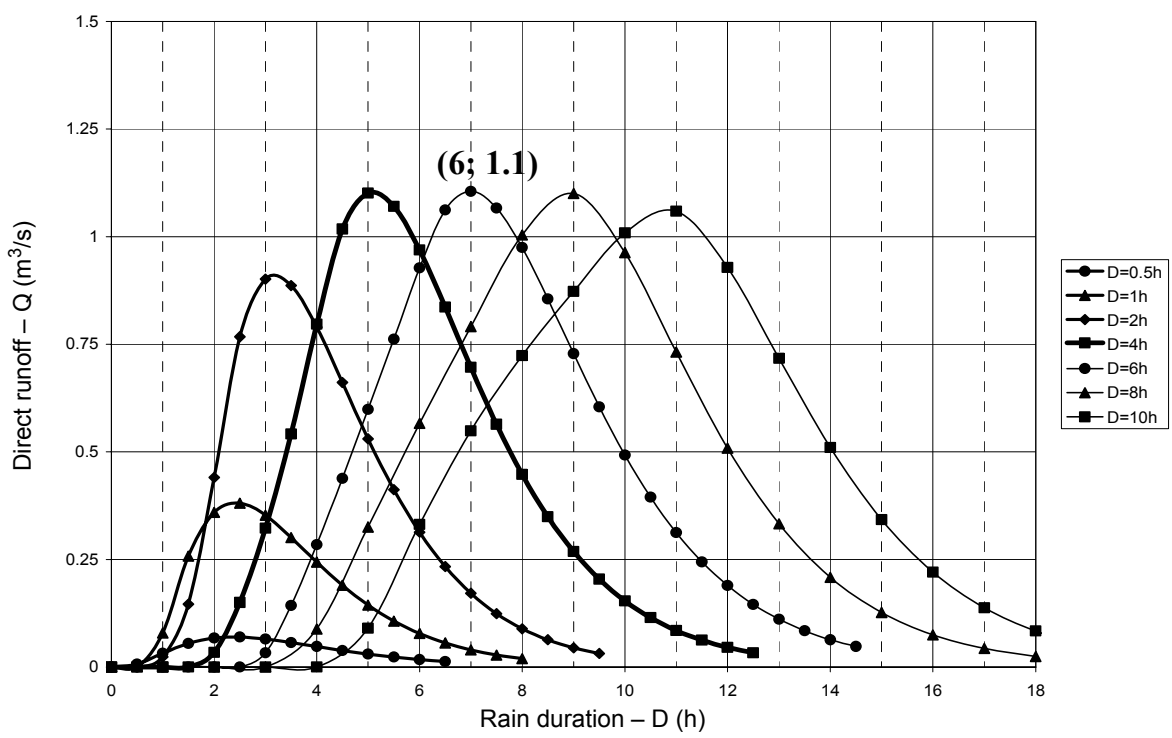

FIGURE 7. Runoff hydrographs caused by rainfall events of return period of 10 years and various duration, at initial land use in the catchment (no urbanisation)

TABLE 3. Estimated peak catchment responses to rainfall events of 10 -year return period and various duration and three stages of land use estimated for 2006, 1985 and $0 \%$ impervious area assumption

\begin{tabular}{|c|c|c|c|}
\hline \multirow{2}{*}{$\begin{array}{l}\text { Rain duration } \\
\mathrm{D}(\mathrm{h})\end{array}$} & \multicolumn{3}{|c|}{ Peak discharges at three stages of land use in the catchment $-\mathrm{Q}_{\max }\left(\mathrm{m}^{3} / \mathrm{s}\right)$} \\
\cline { 2 - 4 } & as in 2006-2009 & as in 1985 & without any urbanization \\
\hline 0.5 & 7.15 & 1.79 & 0.07 \\
\hline 1.0 & 8.83 & 3.03 & 0.38 \\
\hline 2.0 & 8.92 & 4.21 & 0.90 \\
\hline 4.0 & 6.51 & 3.84 & 1.10 \\
\hline 6.0 & 5.83 & 3.16 & 1.10 \\
\hline 8.0 & 5.41 & 2.67 & 1.10 \\
\hline 10.0 & 5.26 & 2.47 & 1.06 \\
\hline
\end{tabular}

peak discharge along with increase of urban development. At the situation of 2006-2009 land use (full urbanisation), the peak discharge is nearly two times higher than the one of 1985 i.e $8.9 \mathrm{~m}^{3} / \mathrm{s}$ at current land use and $4.2 \mathrm{~m}^{3} / \mathrm{s}$ at land use of 1985. In case of initial land use (i.e. assumption for $0 \%$ impervious area and $\mathrm{CN}=69$ ) the peak discharged was $1.1 \mathrm{~m}^{3} / \mathrm{s}$, and has been caused by rain of $\mathrm{D}=6 ; 8 ; 10$ hours. The current catchment response would be over eight times higher than at the agricultural land use. 


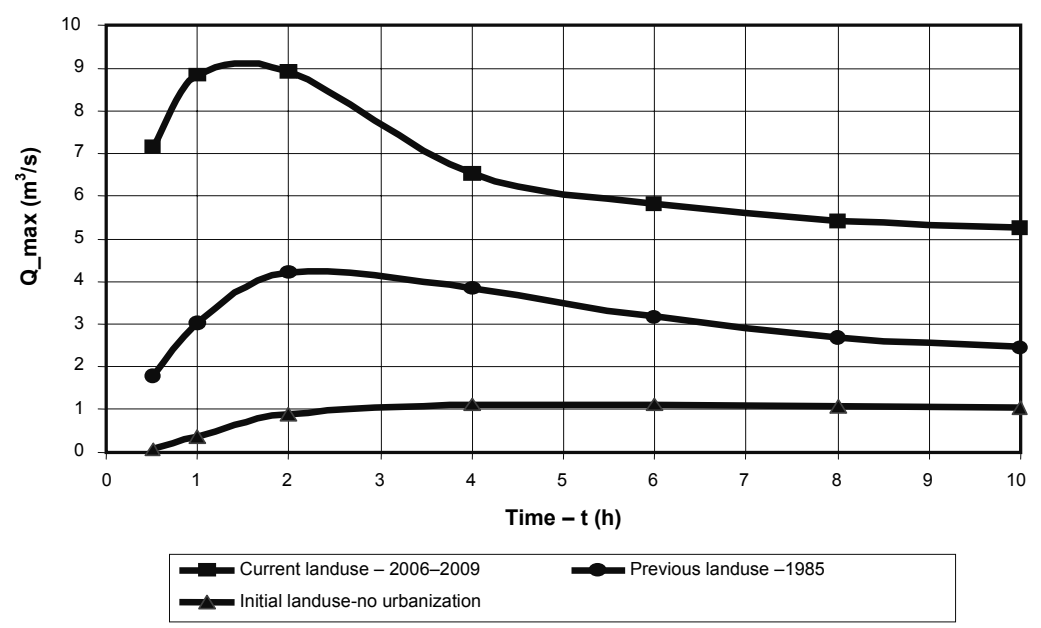

FIGURE 8. Peak discharge of direct runoff hydrographs for three various stages of land use in the catchment versus rainfall duration

\section{CONCLUSIONS}

The aim of this study was to assess the influence of urbanisation on flood hydrograph of a small catchment located in southern part of Warsaw. Based on recorded events a selected procedure for simulation rainfall-runoff process has been accepted for flood estimation. The Soil Conservation Services Curve Number method (SCS-CN) and empirical formulae for Nash model parameters, developed by Rao et al. (1972) were used to analyze the nine selected events from 2007 to 2009 . The catchment, which urbanisation started in the late 70-ties of the previous century, is nearly totally urbanised now. The flood hydrographs, as responses of the catchement to rainfall events of return period of 10-years and various duration, were estimated for three different stages of urbanisation i.e. initial land use (no urbanisation), intermediate one (ca 1985) and the current one.
The CN-SCS method, Nash Model, Rao formulae, GIS and SNE computer program were used to investigate nine selected rainfall-runoff events recorded in the period from 2007 to 2009 and to predict direct runoff hydrographs in a small urbanized catchment of Płaskowicka in the south of Warsaw. The prediction presented how the catchment responds to rainfall events of return period of 10 -years with different duration, for current land use (2006-2009), the earlier land use (1985) and initial one i.e. without no urbanization (1978). The conclusions obtained from this analysis are as follows:

- The selected procedure for rainfallrunoff simulation, based on CN-SCS method for effective rainfall estimation and the Nash model for transformation of effective rainfal into direct runoff hydrographs, allows regenerate recorded runoff hydrographs. This procedure, used with Rao et al. formulae for parameter estimation of 
the Nash model, allowes to analyse influence of urbanisation on flood hydrographs.

- The value of $\mathrm{CN}$, estimated from mean retention parameter $\mathrm{S}$ of recorded events with rainfall depth higher than initial abstraction is approaching the theoretical $\mathrm{CN}$.

- The results of lag times and model parameter estiamted from Rao formulae and from largest recored events are very close to each other.

- Urbanisation of the analysed catchment, from the initial land use as in late 70-ties to the current one, would increase runoff hydrograph peak, as respnse to rainfall events of retern period of 10 years, over eight times (from $1.1 \mathrm{~m}^{3} / \mathrm{s}$ to $8.92 \mathrm{~m}^{3} / \mathrm{s}$ ).

In the further development of the catchment. i.e. with assumption of higher impervious percentage, the peak discharge will be even higher. Unfortunately, economical losses and tragedy can happen even in places where people can feel safe. The results of this study should put an alarm attention for urban planners and for those who are concerned with urban flood management.

Acknowledgment: The investigation described in this paper has been carried out within the ERAMUS MUNDUS Program and the MS-study of the second author at the Warsaw University of Life Sciences - SGGW as well as within research project no. N N305 396238 founded by PLMinistry of Science and Higher Education. The second author wishes to extend her warmest thanks to all those who have helped her with her work and study in the Department of Water Engineering as well as at the Interfaculty Study of Environmental Protection of WULS-SGGW.
The support provided by these organizations is gratefully acknowledged.

\section{REFERENCES}

ANKIEWICZ S. 2003: Analysis of runoff hydrographs from an urban catchment Plaskowicka, MSc thesis, SGGW, (in Polish).

BANASIK K. 2009: Determination of flood hydrograph in small urban catchments (Wyznaczanie wezbrań powodziowych w małych zlewniach zurbanizowanych. Wydawnictwo SGGW, Warszawa).

BANASIK K., HEJDUK L., BARSZCZ M. 2008: Flood flow consequences of land use changes in a small urban catchment of Warsaw, in: 11th International Conference on Urban Drainage, 31 August - 5 September 2008, Edinburgh, Scotland, CD.

BANASIK K., GORSKI D., IGNAR S. 2000: Modeling of precipitation and high water quality not observed outflow from small agricultural catchment (Modelowanie wezbrań opadowych i jakość odpływu z małych nieobserwowanych zlewni rolniczych. Wydawnictwo SGGW, Warszawa).

BANASIK K., WOODWARD D. 2010: Empirical determination of runoff curve number for a small agricultural watershed in Poland. Joint 9th Federal Interagency Sedimentation Conference and 4th Federal Interagency Hydrologic Modelling Conference June 27 - July 1, 2010, CD.

BOGDANOWICZ E., STACHY J. 1998: Computing system of maximal probable rainfall events in Poland (In Polish with an English abstract), Gospodarka Wodna, No 9, 274-279.

CROOKS S., DAVIES H. 2001: Assessment of land use change in the Thames Catchment and its effect on the flood regime of the river. Journal of Physical and Chemistry of the Earth, Part B: Hydrology, Oceans and Atmosphere, Vol. 26, Issues 7-8, p. 583-591. 
HAWKINS R.H. 1993: "Asymptotic determination of curve numbers from data", Journal of Irrigation and Drainage Division, American Society of Civil Engineers, 119(2). p. 334-345.

MAJEWSKI G., PRZEWOŹNICZUK W., KLENIEWSKA K. 2010: Precipitation at the meteorological station Ursynów at WULS-SGGW in 1960-2009 (Warunki opadowe na stacji meteorologicznej Ursynów SGGW w latach 1960-2009). Przegląd Naukowy - Inżynieria i Kształtowanie Środowiska, 48: 3-22.

PHAM N. 2010: Modelling of the effects of land use changes on flood hydrograph, MSc thesis, SGGW, (in Polish).

RAO R.A., DELLEUR I.W., SARMA B.S.P. 1972: Conceptual hydrologic models for urbanization basins. Journal of the Hydraulics Division, Vol. 98(HY7), p. 1205-1220.

SCS (Soil Conservation Service), 1972. USDA-Soil Conservation Service. National Engineering Handbook, Sec. 4, Hydrology, Washington DC.

SCS (Soil Conservation Service), 1986: Urban hydrology for small watersheds. Tech. Report 55, US Dept. of Agric., Washington DC.

Streszczenie: Modelowanie wplywu zmian użytkowania terenu na hydrogramy odplywu wezbraniowego matej zlewni zurbanizowanej ulicy
Płaskowickiej $w$ Warszawie. Przeanalizowano wpływ zmian zagospodarowania terenu (postępującej urbanizacji) na wzrost przepływów wezbraniowych, wywołanych opadem maksymalnym, o różnym czasie trwania i o prawdopodobieństwie przekroczenia $10 \%$. Ustalone $\mathrm{z}$ danych pomiarowych parametry koncepcyjnego modelu opad-odpływ potwierdziły przydatność metody CN-SCS do wyznaczania opadu efektywnego, oraz wzorów Rao, Delleura i Sarmy do wyznaczania parametrów modelu Nasha do transformacji opadu efektywnego w odpływ bezpośredni. Obliczenia wykazały ponadośmiokrotny wzrost przepływów maksymalnych wywołanych opadem o podanej charakterystyce.

Slowa kluczowe: zmiany użytkowania terenu, hydrograf wezbrania, metoda SCS-CN, model opad-odpływ.

\section{MS. received November 15, 2010}

\section{Authors' address:}

Kazimierz Banasik ${ }^{1}$

Ngoc Pham ${ }^{2}$

${ }^{1}$ Department of Water Engineering

kazimierz_banasik@sggw.pl

${ }^{2}$ Interfaculty Study of Environmental Protection ngc.pham@gmail.com ,

Warsaw University of Life Sciences - SGGW

ul. Nowoursynowska 166

02-776 Warszawa

Poland 